\title{
Evaluation of the Crustal Features of the Gulf of Aqaba Deduced from Geophysical Data
}

\author{
A. Z. Hamouda, S. El-Gharabawy \\ Marine Geophysics Lab, National Institute of Oceanography and Fisheries, Alexandia, Egypt \\ Email:suzymooo@yahoo.com
}

How to cite this paper: Hamouda, A. Z., \& El-Gharabawy, S. (2019). Evaluation of the Crustal Features of the Gulf of Aqaba Deduced from Geophysical Data. Journal of Geoscience and Environment Protection, 7, 26-41.

https://doi.org/10.4236/gep.2019.74003

Received: February 28, 2019

Accepted: April 14, 2019

Published: April 17, 2019

Copyright ( 2019 by author(s) and Scientific Research Publishing Inc. This work is licensed under the Creative Commons Attribution International License (CC BY 4.0).

http://creativecommons.org/licenses/by/4.0/

\begin{abstract}
The Gulf of Aqaba is considered as an interesting rift system. Therefore, it is important to understand the crustal features and thickness variation along the Gulf; to be able to evaluate the effect of tectonic activities in shaping the Gulf. The obtained data were used to estimate the reliable empirical relations between the Bouguer anomalies $\left(\Delta \mathrm{g}_{\mathrm{B}}\right)$ and crustal thickness $(\mathrm{Hc})$ in the Gulf of Aqaba. This equation was used to calculate the depth reliefs to the Moho boundary. The output map of the Moho relief and the corresponding crustal thickness were constructed for the Gulf of Aqaba. The depth from sea level down to the Moho discontinuity in the Gulf of Aqaba varies between about $37 \mathrm{~km}$ in the northern deep and abruptly changes to about $28 \mathrm{~km}$ at the southern area, Tiran Strait. Below the central part of the gulf, a Moho depth of about $34 \mathrm{~km}$ is obtained. The Red Sea crust is thinner than that of the Dead Sea rift; indicating the presence of a mantel upwelling that is related to the spreading of the sea floor. The asymmetry of crustal thickness between the eastern and western borders of the Gulf of Aqaba could be attributed to simultaneous strike-slip motion. The relative displacement between the two borders is observed clearly through the sea floor and Moho discontinuity. The displacement is nearly equivalent to $0.18^{\circ}$ (i.e. about $20.4 \mathrm{~km}$ ) and is assumed to be achieved in about 4.08 to 3.4 million years, according to the estimated rate of the transform motion along the Gulf of Aqaba (Dead Sea transform) that is about 0.5 to $0.6 \mathrm{~cm} / \mathrm{y}$.
\end{abstract}

\section{Keywords}

Gulf of Aqaba, Bouguer Map, Bathymetry, Crustal Thickness, Moho

Discontinuity, Tectonics Activity, Red Sea

\section{Introduction}

The data of geophysical survey is a fundamental issue for our understanding of 
the tectonic hazards. The tectonic activity research will thus be helpful to understand the impact of a single and/or group tectonic processes together as a part of evolution of the earth structure and the change of the crust thickness (Shaked et al., 2002). The northern Red Sea-Gulf of Aqaba is a very interesting rift system such as the Gulf of California-Imperial Valley. These are the only two places in the world where a mid-oceanic ridge system changes into a transform system and runs into the continent. The overall tectonic systems are similar in shape and dimensions. The difference is in the direction of the horizontal motion; that the Gulf of Aqaba is left lateral while the Salton Trough region is right lateral. The slip rate is less than $1 \mathrm{~cm} / \mathrm{yr}$ along the Dead Sea rift; while, it is about 5 cm/yr., along the San Andreas Fault (Ben-Averham 1987; Ben-Averham et al., 2005). This is reflected in the seismic activity, heat flow and magmatic activity in these regions (Hamouda, 2006; El-Bohoty et al., 2012; Hartman et al., 2014).

The study covers the area from port of Aqaba at the north to the strait of Tiran at the south in the direction of NNE-SSW with total length of about $180 \mathrm{~km}$. Figure 1 shows the map of the study area. It is narrow in the north $(\sim 5 \mathrm{~km})$ and widens to the south (reaches a maximum width of $28 \mathrm{~km}$ opposite to Dahab). The Gulf has a maximum depth of about $1850 \mathrm{~m}$, with the surrounding mountain rising to about $1.5 \mathrm{~km}$. The volume enclosed by the Gulf of Aqaba is approximately $2250 \mathrm{~km}^{3}$ (Garfunkel et al., 1981; Oswald and Wesnousky, 2002; Ben-Avraham et al., 2005; Hartman et al., 2014).

Previous studies related to the average movement of the Gulf of Aqaba have proposed that, the 40 to $45 \mathrm{~km}$ offset of the Miocene rocks and smaller offsets of the younger features along the Gulf of Aqaba indicate an average shear movement rate of 0.4 to $0.6 \mathrm{~cm} / \mathrm{y}$ during the last 7 to 10 M.y (Ehrhardta et al., 2005;

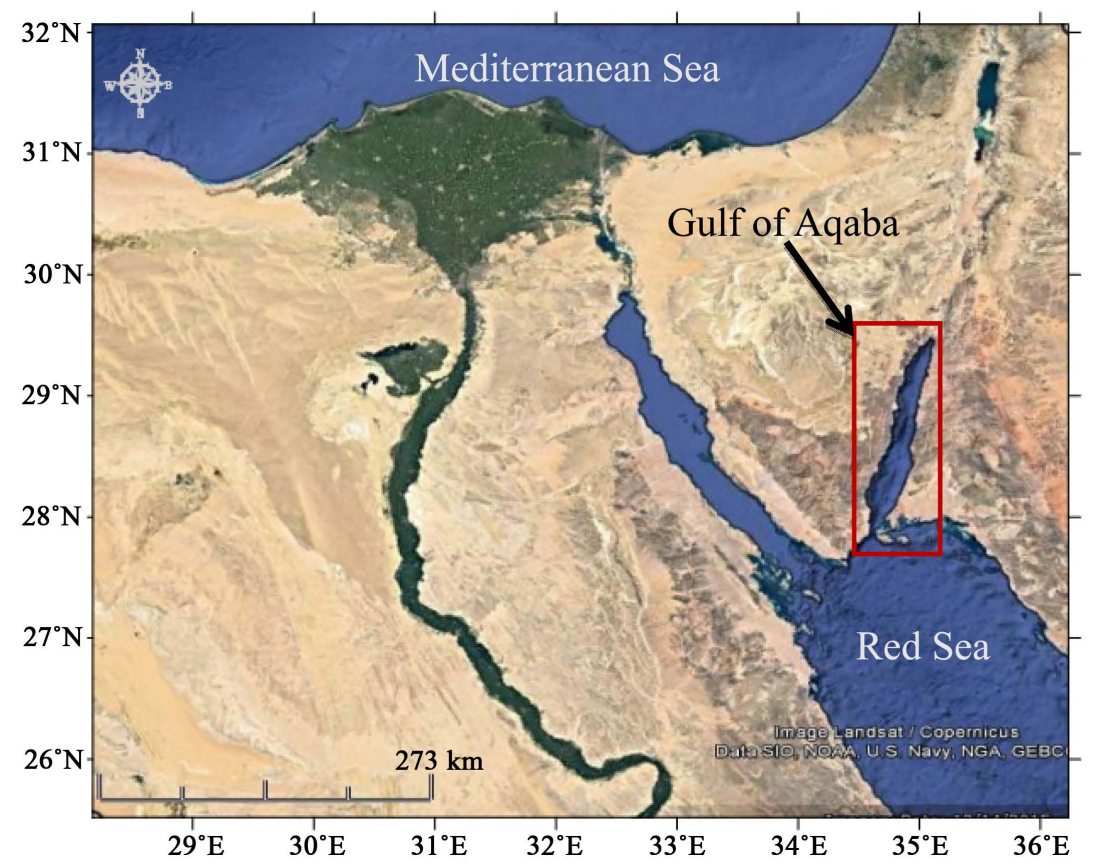

Figure 1. The Location map of the Gulf of Aqaba study area. 
Hamouda, 2011; Saleh et al., 2017; Ribot et al., 2018). Four tectonic stages are believed to have occurred during the Aqaba rifting since the Miocene as follows. The stages are visualized in Figure 2. The first stage was during the Aquitanian-Burdigalian of Early Miocene. In this stage, the NW dikes were intruded concurrent with the normal faulting in the clysmic direction. The second stage was during the Middle to Late Miocene. The first episode of major transcurrent movements along the Aqaba rift took place during this stage (11.5 - 15 M.y ago), as shown by (Steinitz et al., 1978), when the en echelon folds were developed in response to the shearing movements along the deep-seated wrench zone oriented in the NNE direction. After folding, the faults were generated on the surface, associated with pull-aparts and block tilting of 20 to 30 degrees. The third stage was during the Pliocene. The second episode of major sinistral-displacements along the Aqaba transform is believed to have occurred in the Early Pliocene or even later (Steckler et al., 1988). This left-lateral motion was of transtension type resulting in elaboration and manifestation of the pull-apart basins.

This tectonic episode led to regional subsidence, where the Gulf of Aqaba region was connected with the Gulf of Aden, synchronous with the first marine regression in the late Pliocene. The fourth stage was during the Post Pliocene-Late Holocene. After the deposition and consolidation of the Pliocene beds, tilting of the fault blocks was elaborated reaching $45^{\circ}$ in many areas, as indicated from the tilted Raham formation of Wadi Haimur area. During this stage, the shoulders of the Gulf of Aqaba were uplifted with the narrowing of the subsided areas, where the first deposited Pliocene marine sediments were raised on either side of the Gulf, (e.g. Ras Barqa area), as exhibited by (Bayer et al., 1988).

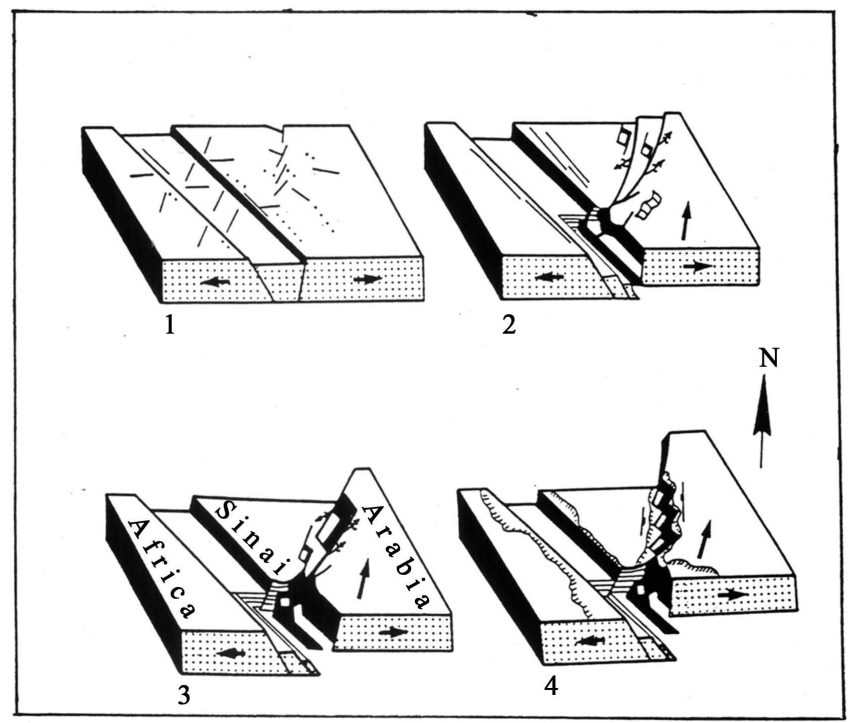

Figure 2. Simplified block diagrams showing the structural evolution of the Gulf of Aqaba transform. The interpretation of the Aqaba entrance is after (Bayer et al., 1988). (1) Aquitainian-Burdigalian (2) Late Miocene, (3) Pliocene, and (4) Post Pliocene-Late Holocene stages. 
This study is aiming to understand the recent features situation of the Moho discontinuity and crustal thickness of the Gulf of Aqaba. We need to evaluate how the tectonic activity of the Gulf of Aqaba impacts the crustal thickness and the Moho discontinuity, and whether there is asymmetry in the crustal thickness along the Gulf of Aqaba or not. This evaluation is based on the gravity data and deep seismic profiles.

\section{Collected Data}

The Bathymetry and Bouguer anomaly data (in digital form) was obtained and collected from different published sources such as the National Geophysical Data Center (USA). Bouguer anomaly map of our study area (Northern Red Sea and southeastern Mediterranean), at a constant contour interval of $5 \mathrm{mGal}$, has been re-gridded by the World Gravity Map project team (WGM), from various published maps (Allan \& Morelli, 1970; Riad, 1977; Woodside, 1977; EGPC, 1980; Folkman \& Assael, 1980; Tealeb \& Riad, 1986; Ben-Averaham, 1987; Martinez \& Cochran, 1988; Ginzburg et al., 1993; Makris \& Wang 1994; Rybakov et al., 1997; Segev et al., 2006). The Marine gravity data in the northern Red Sea were collected from publications (Martinez \& Cochran, 1988), whereas in Southeastern Mediterranean were taken from publications (Woodside, 1977; Ginzburg et al., 1993; Makris \& Wang 1994).

All of these maps were digitized each $0.01 \mathrm{~km}$ grids. The Surfer program software was used to construct the compiled Bouguer map of the Gulf of Aqaba. The total number of digitized gravity anomaly values was 8815 .

\section{Methodology}

For regional areas, the Bouguer anomaly is found to be closely related to crustal thickness. The fundamental background of an anomalous gravitational field is determined by the relief of the Moho, which permits the thickness of the crust to be calculated from gravity (Bouguer) anomalies. Much work has been published giving calculations of the crustal thickness in one area or another from gravity anomalies (Pick et al., 1973; Riad et al., 1983; Riad \& El-Etr, 1985). Several empirical formulae representing the relations between the gravity anomalies and crustal structure, deduced from deep seismic recording, were calculated for different areas worldwide. The individual areas were shown to be characterized by different forms and degrees of relationship between the parameters of gravity and crustal thickness.

Much information has been gained concerning the shallow and deep crustal structure of the Gulf of Aqaba starting from 1981 by (Ginzburg et al., 1979; Riad et al., 1983; Ben-Averham, 1987; Ben-Averham \& Zoback, 1992). Three deep seismic refraction profiles were used in calculating the thickness of the crust in the Gulf of Aqaba (after (Ginzburg et al., 1979; Ginzburg et al., 1981)). The first profile is parallel to the strike axis of the gulf while, the other two are crossing the strike axis of the gulf. The obtained empirical relations between crustal 
thickness and Bouguer anomalies can be applied on the Gulf of Aqaba. The Bouguer values are used for an average grid spacing of $\left(5^{\prime} \times 5^{\prime}\right)$.

The correlation between the Bouguer anomaly and the depth to the Moho discontinuity is done in the Gulf of Aqaba, by using the regression analysis (Spiegal, 1972) assuming a linear model of the subsurface medium. Gravity anomalies of wavelengths $(\lambda)$ equal to 2 and $5 \mathrm{kms}$ (i.e. digitized each $2 \& 5 \mathrm{~km}$ grid spacings, respectively), and the corresponding values of crustal thicknesses along the three deep seismic refraction profiles (Figure 3), were used for calculating the regression equation, standard deviation (SD) and correlation coefficients $(r)$, by utilizing Statgraph Program. Figure 4 shows the Bouguer anomalies versus the crustal thickness plots.

Accordingly, the empirical relations between the Bouguer anomalies $\left(\Delta g_{B}\right)$ and the crustal thickness $(H c)$ in the Gulf of Aqaba area were found to be:

$$
H c=28.6-0.079 \Delta g_{B}
$$

for $\lambda=2 \mathrm{~km}$, where:

$$
\mathrm{SD}=2.99 \& r=-0.63
$$

$$
H c=28.6-0.079 \Delta g_{B}
$$

for $\lambda=5 \mathrm{~km}$, where:

$$
\mathrm{SD}=1.18 \& r=-0.80 \text {. }
$$

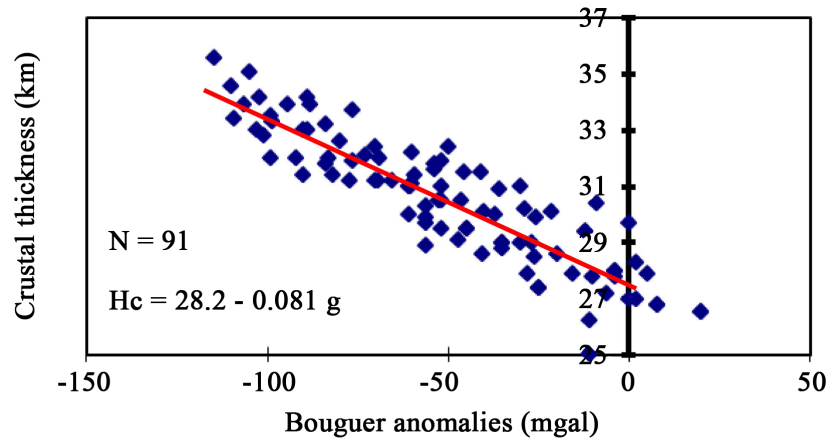

(a)

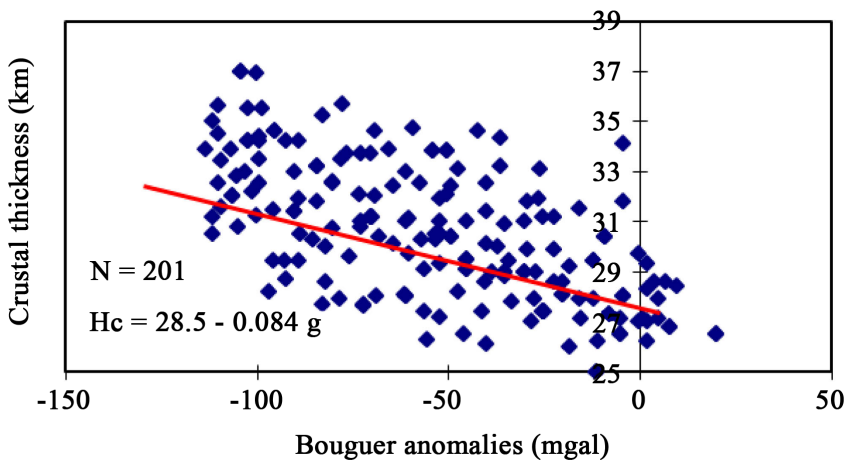

(b)

Figure 3. The correlation between the crust thickness and the Bouguer anomalies of wavelengths $(\lambda=5 \mathrm{~km}$ and $\lambda=2 \mathrm{~km}$ ). (a) Relation between crustal thickness and Bouguer anomalies (Digitized at $5 \mathrm{~km}$. grids); (b) Relation between crustal thickness and Bouguer anomalies (Digitized at $2 \mathrm{~km}$. grids). 


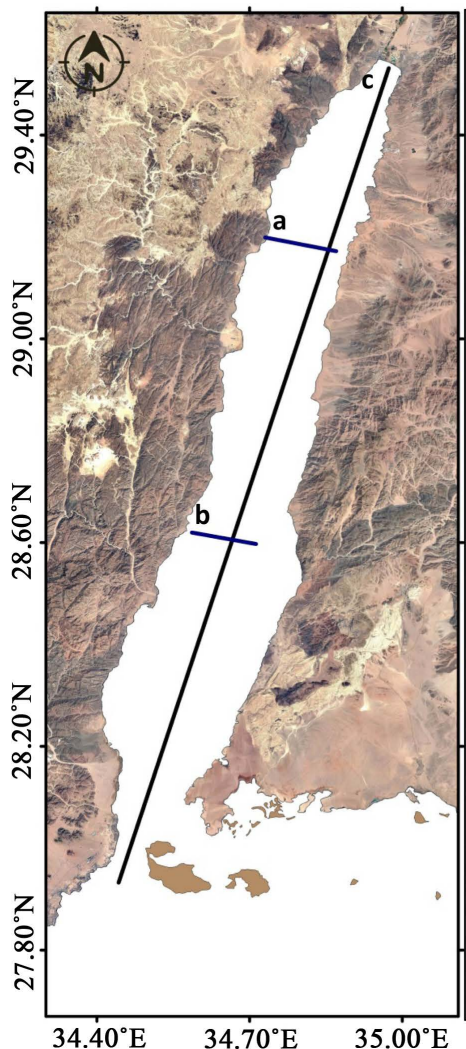

(a)
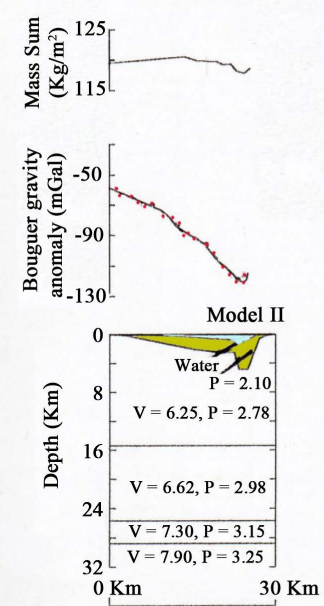

(b)

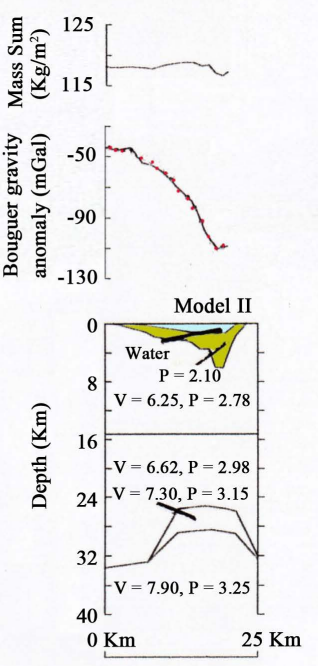

(c)

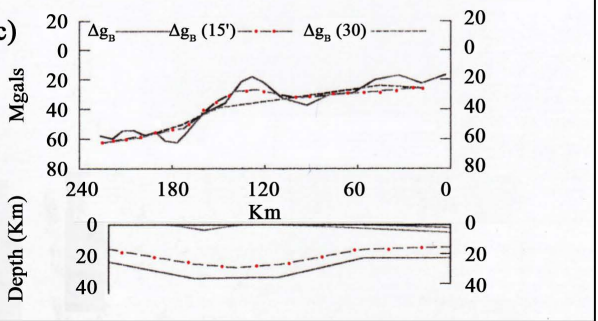

Figure 4. Three sections represent the structure of the Crust and Bouguer gravity along profiles of the Gulf of Aqaba (after: Ginzburg et al., 1979; Ginzburg et al., 1981).

The values of "SD" and " $r$ " show that, Equation (2) is more reliable for the detailed mapping of the relief to the Mohorovicic boundary in the Gulf of Aqaba. This equation was used to calculate the depth reliefs to the Moho boundary in the Gulf of Aqaba.

\section{Results and Discussion}

\subsection{Bathymetric Map}

The bathymetric map of the Gulf of Aqaba resulting from the digitization of all the available published data of the Gulf of Aqaba was illustrated in (Figure 5). The Gulf of Aqaba is composed of three deep and elongated basins, striking $\mathrm{N} 20^{\circ}-25^{\circ} \mathrm{E}$. These basins are separated by shallow sills, and accordingly the Gulf is divided into three distinct parts. The floors of these basins are undulated, and several distinct deeps are formed. It is noticed that the northern part of the Gulf has a relatively simple bathymetry, and is dominated by the flat-bottomed Elat Deep, about $50 \mathrm{Km}$ long and $3-8 \mathrm{~km}$ wide, that is considered the largest basin in the Gulf, in addition to being the shallowest (about $900 \mathrm{~m}$ ). The area of the central basin is about $35 \mathrm{~km}$ long and about $6 \mathrm{~km}$ wide. It includes the deepest areas in the Gulf, the Aragonese Deep ( $\approx 1850 \mathrm{~m}$, towards the Eastern side) and Arnona Deep ( $\approx 1550 \mathrm{~m}$, towards the western side), which are separated by a shallow intrabasin sill. The Aragonese Deep covers about $6-8 \mathrm{~km}$ by $2 \mathrm{~km}$; 


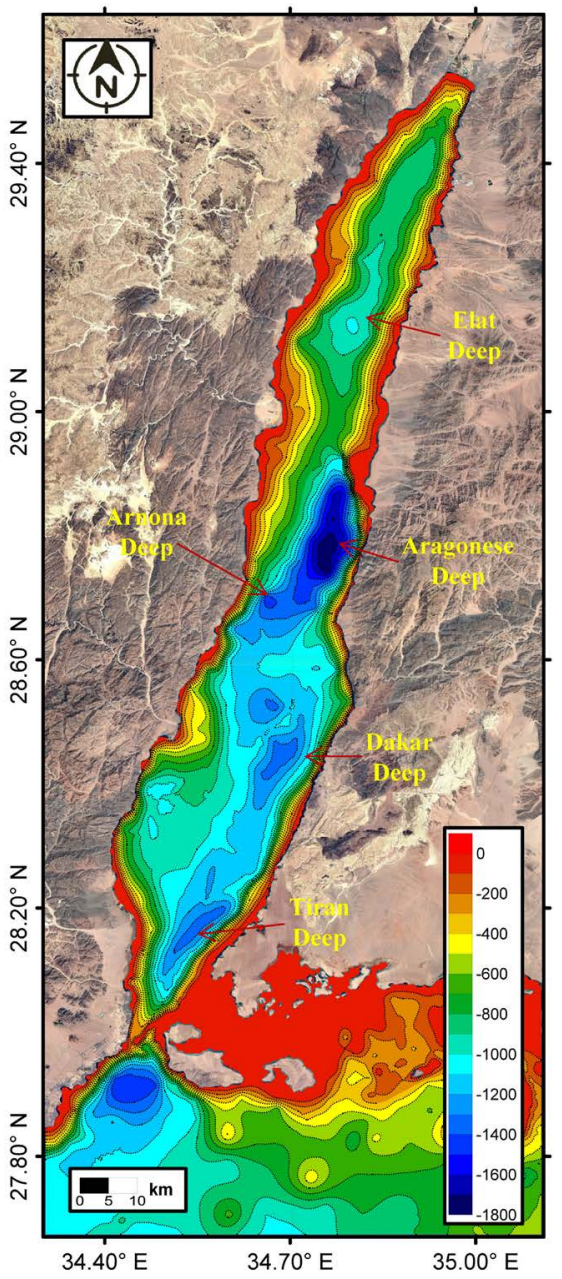

Figure 5. The bathymetric map of the Gulf of Aqaba.

while the Arnona Deep covers about $4-5 \mathrm{~km}$ by $1 \mathrm{~km}$ area. Also, it includes the Dakar deep of area about $18 \mathrm{~km}$ by $4 \mathrm{~km}$ and $1400 \mathrm{~m}$ depth; and the Tiran deep of $18 \mathrm{~km}$ by $3 \mathrm{~km}$ area and $1300 \mathrm{~m}$ depth. At the Straits of Tiran, it can be noticed that the Gulf is separated from the Hume Deep and the Red Sea by a threshold whose present maximum depth is about $252 \mathrm{~m}$.

The Gulf of Aqaba is characterized by the absence of the continental shelves and there are no coastal plains or they are very narrow. The prolongation of large alluvial fans as submarine cones incised many canyons on its western side. These cones are built on sloping terraces where the western margin is characterized by large fans of Wadi Dahab and Wadi Kid. On the other hand, the eastern margin inclines sharply to the deep basins. Eastern boundary shows a steep and slopes reach about $25^{\circ}$ to $30^{\circ}$, whereas those on the west reach about $16^{\circ}$ and less.

\subsection{Bouguer Gravity Map}

Examination of the collected Bouguer gravity map (Figure 6) indicates the presence of two low gravity anomalies on the Gulf of Aqaba. The northern one is 


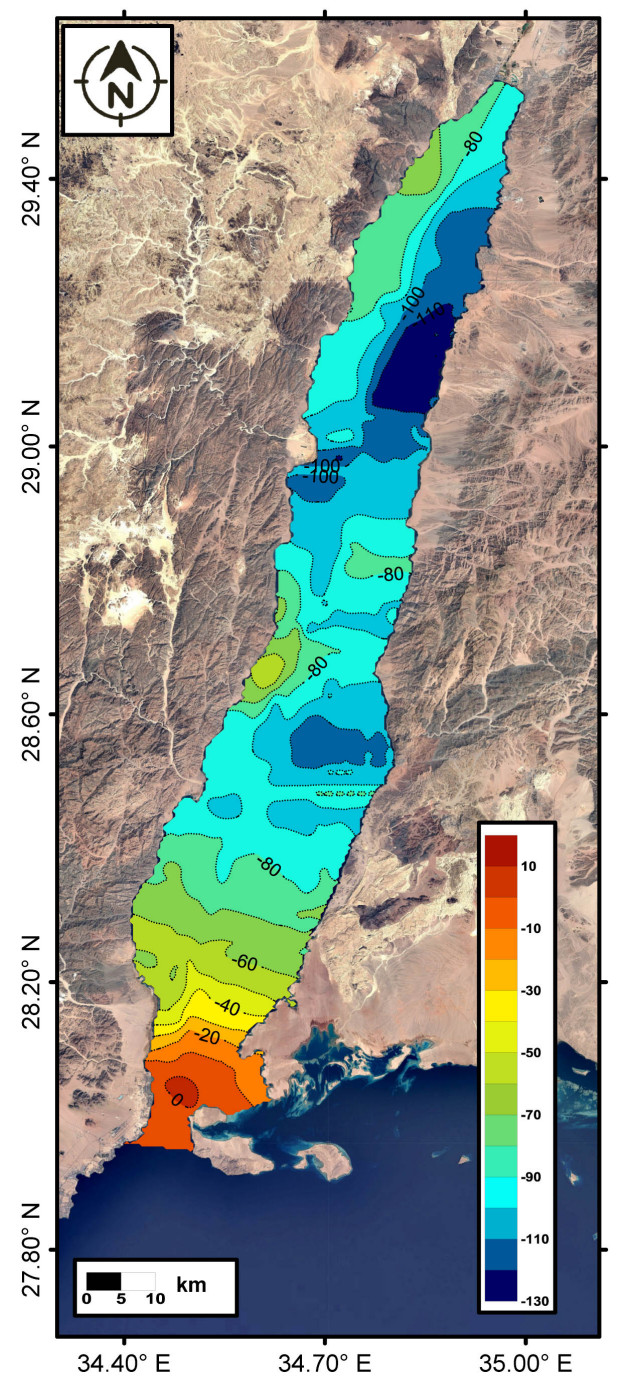

Figure 6. The Bouguer gravity map of the Gulf of Aqaba.

much larger in area than the southern one. The northern part is characterized lowest anomalies between -120 and -70 mgals, and lies over the northern basin (Elat Deep), while the central part has lower anomalies between -100 and -60 mgals and covers the area between Aragonese and Dakar deeps. The southern part has Bouguer anomalies vary from -70 up to -10 magls and covers Tiran deep. These variations of Bouguer gravity anomalies are observed in between each part (north, central and southern parts) and in between eastern and western side of the Gulf. Therefore, the asymmetric variation of the curst thickness is obvious along the Gulf of Aqaba. It seems that the active tectonic processes may have affected the crust thickness at the central part and separated the gulf into two belt structures. One of these belts is found to the north, while the second is found in the central part of the gulf and they are separated by high belt structure.

The positive Bouguer anomalies ( $\approx 40 \mathrm{mgal}$ ) that located at the northern end of the Red Sea, decrease to about $20 \mathrm{mgal}$ at the southern tip of Sinai, adjacent to the mouth of the Gulf of Aqaba and reaches zero at the vicinity of Tiran strait, 
and then decrease to about -100 mgal. This may indicate a crustal variation or crustal thinning. Accordingly, we can conclude that, the deep structure of the gulf is not connected to the Red Sea. However, the presence of large negative anomalies cannot be always used as a criterion for crustal separation (Hamouda, 2000; Prutkina \& Saleh, 2009) and probably may indicate lava flows overlying regions of high density.

\subsection{Moho Discontinuity \& Crustal Thickness}

A map representing the Moho relief in the Gulf of Aqaba is shown in (Figure 7), and (Figure 8) illustrates the crustal thickness map that was constructed from the corresponding three dimensional configurations.

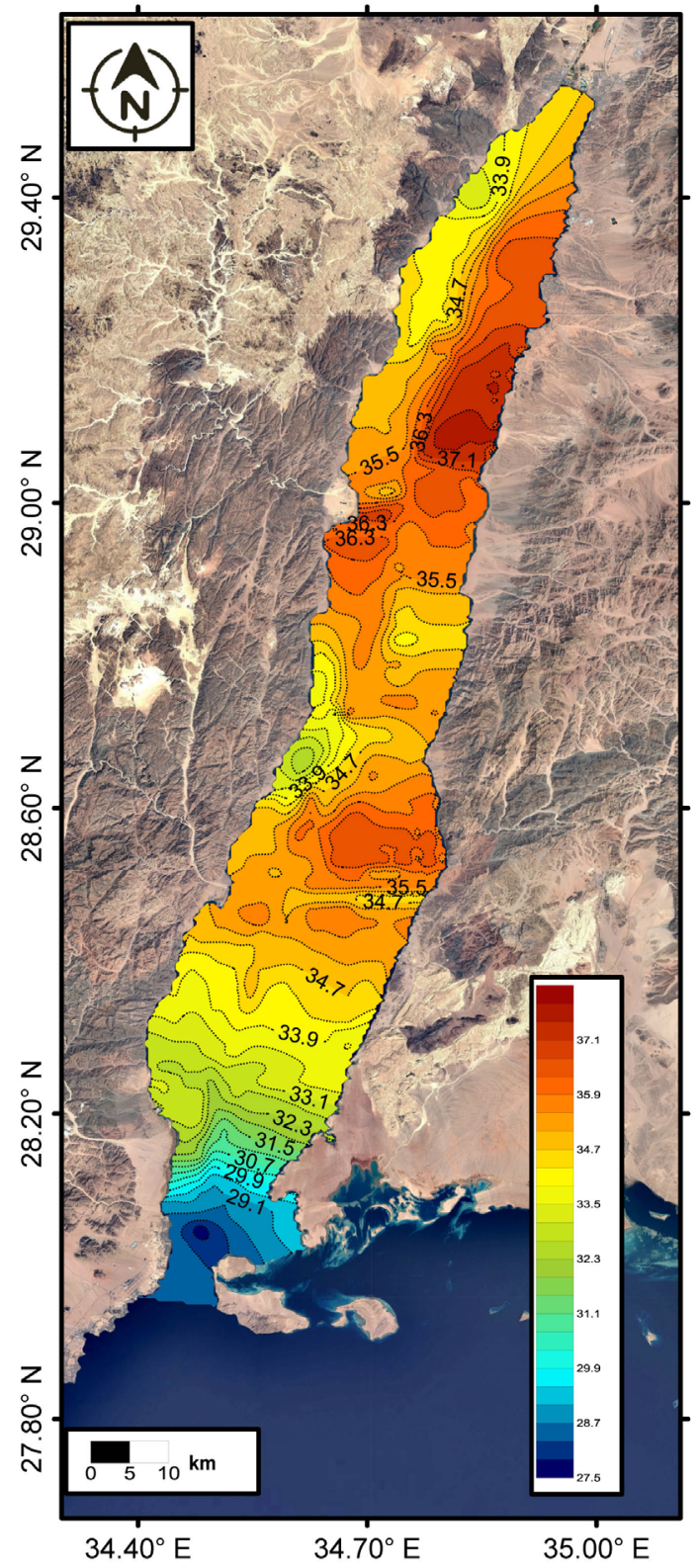

Figure 7. The Moho relief of the Gulf of Aqaba. 


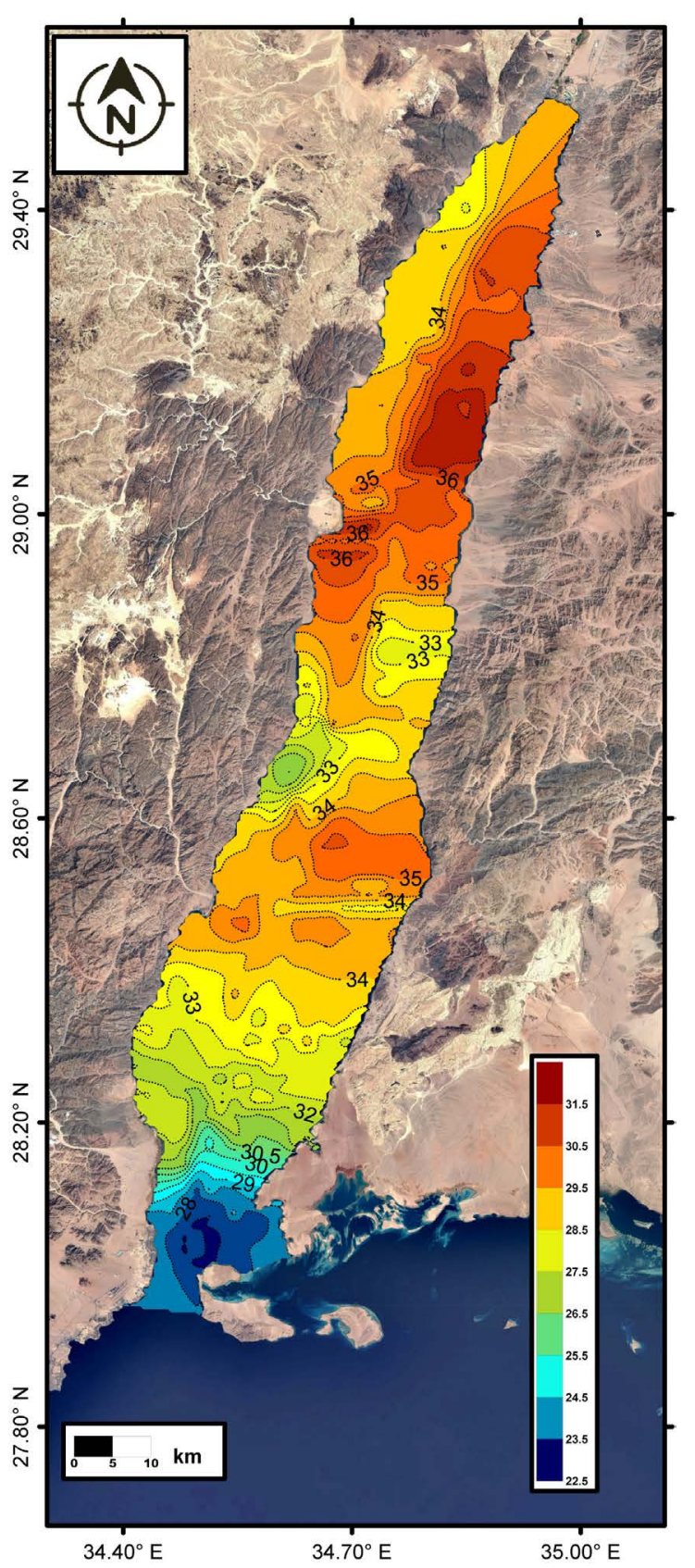

Figure 8. The crustal thickness of the Gulf of Aqaba.

The depth from mean sea level down to the Moho discontinuity in the Gulf of Aqaba varies between depths of $35 \mathrm{~km}$ in the northern Elat Deep and with abruptly change about $28 \mathrm{~km}$ at the southern area, Tiran Strait. Below the central part of the gulf, a Moho depth of about $34 \mathrm{~km}$ was obtained. Accordingly, it seems that, the Gulf of Aqaba has a transition phase taking place from the points of the structure or crustal thickness of the Red Sea to that of the Dead Sea rift. The crustal thinning in this area may indicate mantle upwelling, which is probably related to sea floor spreading (Hartman et al., 2014, El-Khrepy at al., 2016; Bosworth et al., 2017). 
Figure 9 shows the geophysical data (Bathymetry, Bouguer gravity anomalies and depth of Moho discontinuity) along the two profiles (EE') and (WW') of the Gulf. The profiles provide a comparative study between various types of geophysical data.

The profile (EE') of the eastern border shows that, the Aragonese deep and Dakar deep are characterized by variation of the depth of Moho discontinuity. The profile $\left(\mathrm{WW}^{\prime}\right)$ of the western border shows the variation of the depth of the Moho discontinuity at the Arnona deep and the western side of Elat deep. The study of crustal deformations underneath the Gulf of Aqaba basin can be achieved through the comparison between the same parameters, when measured along the Eastern (EE') and Western (WW') borders of the gulf (Figure 9). It is noticed that, the most deformed area is the central part of the Gulf of Aqaba, which lies between latitudes $28.5^{\circ}$ and $28.9^{\circ}$, where the trend of deformation extends to the north. The crustal thinning along the Gulf of Aqaba is about $9 \mathrm{~km}$, where it decreases from about $37 \mathrm{~km}$ in the northern part of the gulf to about 28 $\mathrm{km}$ in its southern portion.

In general, the Moho discontinuity and the seafloor of the eastern profiles appear as mirror to western side (Figure 9). The western side appear as shifted or
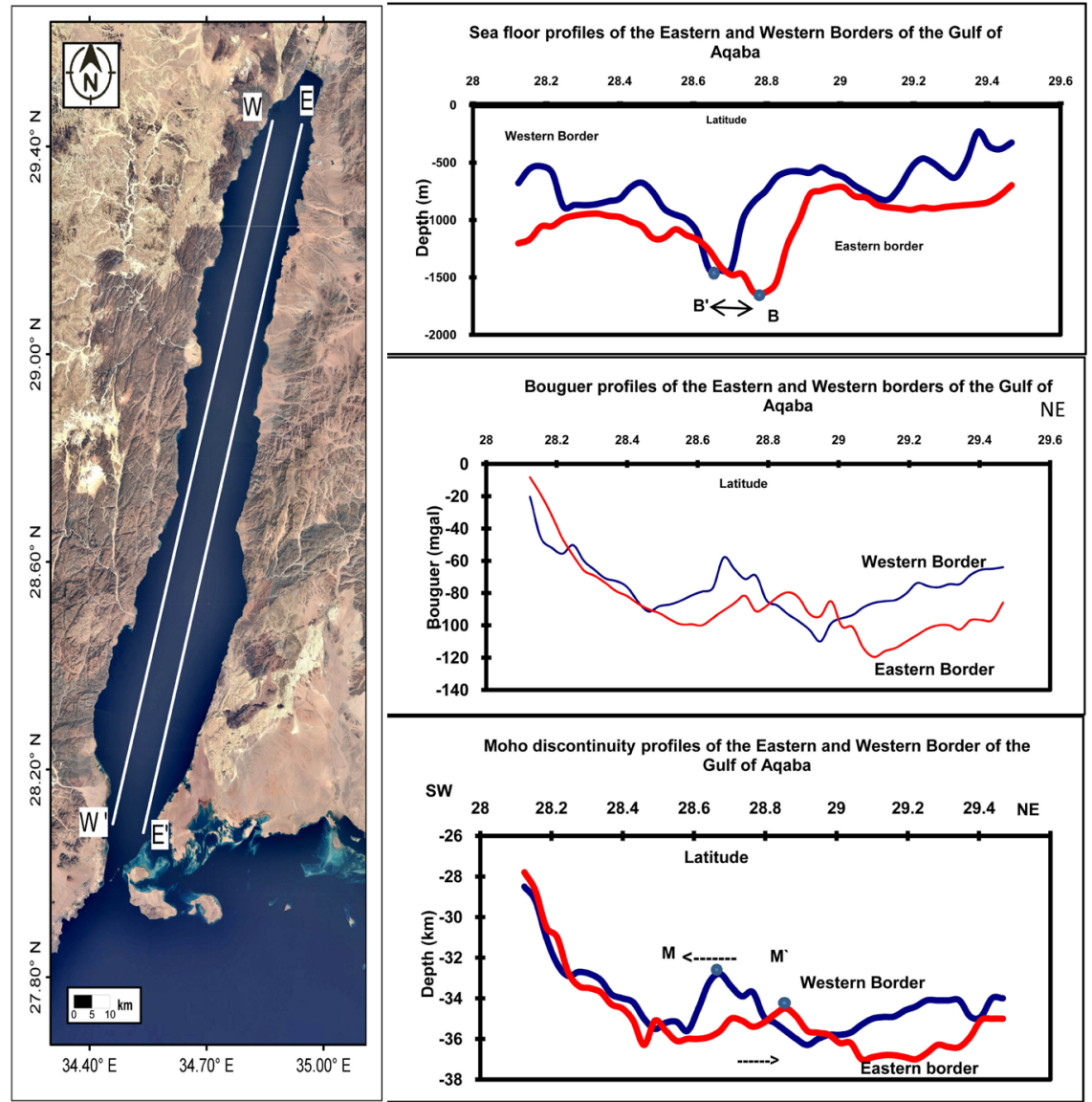

Figure 9. Bathymetry, Bouguer anomalies and depth of Moho discontinuity along the two profiles (EE') and (WW'). 
movements towards the NE direction which reflect their left strike movement and slightly deeper than the eastern side. The asymmetry of crustal thickness along the two profiles of the eastern and western borders (EE' \& WW') of the Gulf of Aqaba could be attributed to simultaneous strike-slip motion. The Moho discontinuity in the central part of the gulf (Aragonese and Arnona basin) is characterized by highly deformed area along the Gulf of Aqaba. The thinning crustal is observed in the southern part of the gulf (Figure 9).

The variation in crustal thickness is not only observed along the length of the gulf (NNE-SSW), but also across the gulf itself. This variation is clearly observed through the two profiles across the central part of the gulf (between lat. $28.5^{\circ} \&$ $28.8^{\circ}$ ) around the Aragonese and Arnona Deeps. The other crustal thickness variation is observed along the two profiles at Elat Deep, which extends from Latitude $29^{\circ}$ to $29.4^{\circ}$.

The asymmetry of crustal thickness along the two profiles of the eastern and western borders is evidenced may be from the relative displacement between the two profiles, which is observed clearly through the sea floor and Moho discontinuity depths. The displacement between the two deepest points (B \& B'), on the two sea floor profiles is nearly equivalent to the displacement between the deepest two points ( $M \& M^{\prime}$ ) of the two Moho discontinuity profiles. This displacement is equivalent to $0.18^{\circ}$ (i.e. about $20.4 \mathrm{~km}$ ) and is assumed to be achieved in about 3.4 to 4.08 to million years, according to the estimated rate of the transform motion along the Gulf of Aqaba (Dead Sea transform), which is about 0.5 to $0.6 \mathrm{~cm} / \mathrm{y}$ (Joffe \& Garfunkel, 1987).

The tectonic activity, which affects the Moho discontinuity, has left its imprints on the sea floor of the Gulf of Aqaba. According to (Sibson, 1983) evidences; from inactive strike-slip faults and other erosions to expose the lower crustal parts; he suggested a continuous vertical transition from brittle deformation near the surface to ductile deformation at the middle to the lower crustal depths (Figure 10). At the surface, the elastic strain energy would be relieved by instantaneous strike-slip rebound, as indicated by cataclastic rocks (breccia and gouge). At depth, this motion may occur as ductile creep, continuously producing mylonite and other ductility deformed rocks. The zone of ductile-brittle transition may be characterized by high activity of earthquake hypocenters (Al-Arifi et al., 2012).

The transform of displacement motion, which is observed along the two borders of the gulf, may be related to the effect of the total displacement of the main Dead Sea transform, which can be observed at the surface along the Dead Sea rift, and may be also the effect of the depths of Moho discontinuity. If this occurs at the central part of the Gulf of Aqaba, we can expect the mantle upwelling, as indicated in the Bouguer anomaly profiles. This upwelling could be associated with tectonic activity, which leads to a widening of the rift zone and to continental splitting. 


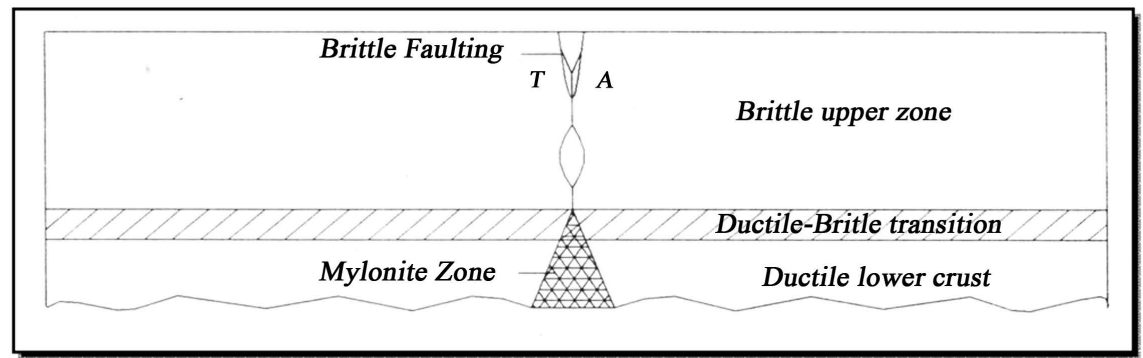

(A)

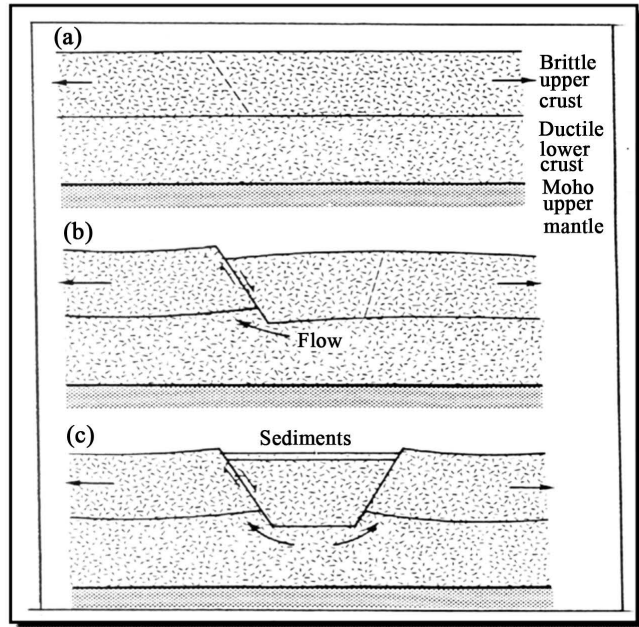

(B)
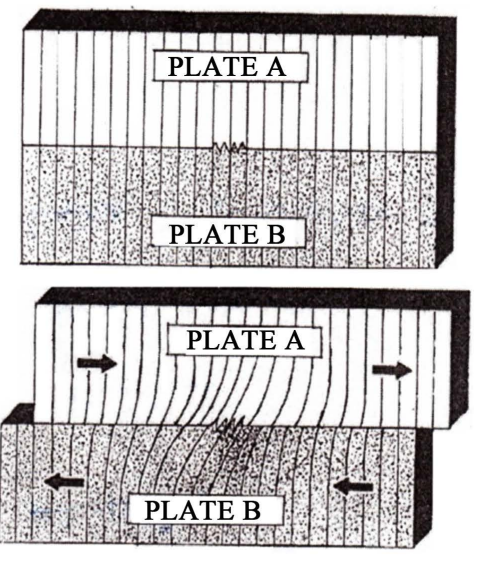

(C)

Figure 10. (A) Along a strike-slip fault, the deformation type and kind of fault rock both vary with depth in the crust; (B) Development of the rift valley by faulting in the upper crust and ductile flow in the lower crust; (C) Friction between plates A and B is concentrated at the rough spot near the center of the fault, elastic energy is stored in the rocks adjacent to the rough spot crowing, crowing together of lines indicates regions of compression (after: Sibson, 1983).

\section{Conclusion}

The structure of the crustal thickness, which is obtained by gravity, is correlated well with the seismic section values which are reasonable tools to discuss the crustal thickness and tectonic structure of the gulf. The structures of the Gulf of Aqaba, as deduced from the geophysical analysis are relevant to the neotectonics indicating that, the central part of the gulf is highly deformed. This may be related to upwelling of the mantle in this region which leads to increase earthquake activity at this part.

The Gulf of Aqaba is affected by the presence of some local features, which reflect their left strike movement behavior. This is spotted on the north-east and center of the Gulf. It can be noticed that, the crust is probably thinner over the deepest part of the gulf and around it, where most of the tectonic activities exist. The depth of the Moho is shallower compared to the other two parts of the gulf. This reflects that the Gulf of Aqaba is characterized by a series of morphotectonic depressions with leaky movement along left lateral transform faults. The shape and relief of the Moho boundary of the Gulf of Aqaba are not uniform or homogeneous. This in homogeneity and asymmetry may be related to the im- 
pact of the major structure and tectonic activity of the Northern Dead Sea rift and the Southern Red Sea spreading.

The rough asymmetry of the basins along the continental transform faults of the gulf may be related to the impact of horizontal principal stresses effect on weak fault in strong crust. This leads to the orientation of the movement parallel and slightly perpendicular to the main strike slip fault.

These vast negative anomalies on the Gulf of Aqaba might be identified with the development of the oceanic lithosphere from the northern Red Sea to the Gulf of Aqaba. The central part of the ocean floor (the deepest area) of the gulf counts as major tectonically active spot. This can be observed from the records of the earthquakes actions. The variation of the depth of the Moho discontinuity may relate to slight upwelling of the mantel.

\section{Conflicts of Interest}

The authors declare no conflicts of interest regarding the publication of this paper.

\section{References}

Al-Arifi, N. S., Lashin, A. A., \& Al-Humidan, S. (2012). Migration of Local Earthquakes in the Gulf of Aqaba, North Red Sea. Earth Sciences Research Journal, 16, 35-40.

Allan, T. D., \& Morelli, C. (1970). The Red Sea. In A. E. Maxwell (Ed.), The Sea (pp. 493-542). New York: Wiley InterScience.

Bayer, H. J., Hötzl, H., Jado, A. R., Roscher, B., \& Voggenreiterm, W. (1988). Sedimentary and Structural Evolution of the Northwest Arabian Red Sea Margin. Tectonophysics, 153, 137-151. https://doi.org/10.1016/0040-1951(88)90011-X

Ben-Averham, Z. (1987). Rift Propagation along the Southern Dead Sea Rift (Gulf of Elat). Tectonophysics, 143, 193-200. https://doi.org/10.1016/0040-1951(87)90088-6

Ben-Averham, Z., \& Zoback, M. D. (1992). Transform-Normal Extension and Asymmetric Basins: An Alternative to Pull-Apart Models. Geology, 20, 423. https://doi.org/10.1130/0091-7613(1992)020<0423:TNEAAB>2.3.CO;2

Ben-Averham, Z., Lazar, M., Schattner, U., \& Marco, S. (2005). The Dead Sea Fault and Its Effect on Civilization. In F. Wenzel (Ed.), Lecture Notes in Earth Sciences: Perspectives in Modern Seismology (pp. 145-167). Heidelberg: Springer.

Bosworth, W., Montagna, P., Pons-Branchu, E., Rasul, N., \& Taviani, M. (2017). Seismic Hazards Implications of Uplifted Pleistocene Coral Terraces in the Gulf of Aqaba. Scientific Reports, 7, Article No. 38. https://doi.org/10.1038/s41598-017-00074-2

Egyptian General Petroleum Corporation (EGPC) (1980).

Ehrhardta, A., Hqbschera, C., Ben-Avraham, Z., \& Gajewski, D. (2005). Seismic Study of Pull-Apart-Induced Sedimentation and Deformation in the Northern Gulf of Aqaba (Elat). Tectonophysics, 396, 59-79. https://doi.org/10.1016/j.tecto.2004.10.011

El-Bohoty, M., Brimich, L., Saleh, A., \& Saleh, S. (2012). Comparative Study between the Structural and Tectonic Situation of the Southern Sinai and the Red Sea, Egypt, as Deduced from Magnetic, Gravity and Seismic Data. Contributions to Geophysics and Geodesy, 42, 357-388.

El-Khrepy, S., Koulakov, I., Al-Arifi, N., \& Petrunin, A. G. (2016). Seismic Structure beneath the Gulf of Aqaba and Adjacent Areas Based on the Tomographic Inversion of Regional Earthquake Data. Solid Earth, 7, 965-978. 
https://doi.org/10.5194/se-7-965-2016

Folkman, Y., \& Assael, R. (1980). Preparing of Aeromagnetic Map of Sinai, Egypt. The Institute for Petroleum Research and Geophysics.

Garfunkel, Z., Zak, I., \& Freund, R. (1981). Active Faulting in the Dead Sea Rift. Tectonophysics, 80, 1-26. https://doi.org/10.1016/0040-1951(81)90139-6

Ginzburg, A., Folkman, Y., Rybakov, M., Rotstein, Y., Assael, R., \& Yuval, Z. (1993). Bouguer Gravity Map of Israel and Adjacent Areas (1:500,000).

Ginzburg, A., Makris, J., Fuchs, K., \& Prodehl, C. (1981). The Structure of the Crust and Upper Mantle in the Dead Sea Rift. Tectonophysics, 80, 109-119. https://doi.org/10.1016/0040-1951(81)90144-X

Ginzburg, A., Makris, J., Fuchs, K., Perathoner, B., \& Prodehl, C. (1979). Detailed Structure of the Crust and Upper Mantle along the Jordan-Dead Sea. Journal of Geophysical Research, 84, 5605-5612. https://doi.org/10.1029/JB084iB10p05605

Hamouda, A. Z. (2000). Study of the Neotectonics in the Gulf of Aqaba, Red Sea, as Revealed from Marine Geophysical Data. PhD Thesis, Alexandria: University of Alexandria.

Hamouda, A. Z. (2006). Seismic Hazard of the Eastern Mediterranean. Acta Geophysica, 54, 165-176. https://doi.org/10.2478/s11600-006-0013-Z

Hamouda, A. Z. (2011). Recent Evaluation of the Assessment Seismic Hazards for Nuweiba, Gulf of Aqaba. Arabian Journal of Geosciences, 4, 775-783. https://doi.org/10.1007/s12517-009-0096-3

Hartman, G., Niemi, T. M., Tibor, G., Ben-Avraham, Z., Al-Zoubi, A., Makovsky, Y., Akawwi, E., Abueladas, A., \& Al-Ruzouq, R. (2014). Quaternary Tectonic Evolution of the Northern Gulf of Elat/Aqaba along the Dead Sea Transform. Journal of Geophysical Research: Solid Earth, 119, 9183-9205.

Joffe, S., \& Garfunkel, Z. (1987). Plate Kinematics of the Circum Red Sea-A Re-Evaluation. Tectonophysics, 141, 5-22. https://doi.org/10.1016/0040-1951(87)90171-5

Makris, J., \& Wang, J. (1994). Bouguer Gravity Anomalies of the Eastern Mediterranean Sea. In V. A. Krasheninnikov, \& J. K. Hall (Eds.), Geological Structure of the North-Eastern Mediterranean: Jerusalem (pp. 87-98). Historical Productions Hall Ltd.

Martinez, F., \& Cochran, J. R. (1988). Structure and Tectonic of the Northern Red Sea: Catching a Continental Margin between Rifting and Drifting. Tectonophysics, 150, 1-32. https://doi.org/10.1016/0040-1951(88)90293-4

Oswald, J. A., \& Wesnousky, S. G. (2002). Neotectonics and Quaternary Geology of the Hunter Mountain Fault Zone and Saline Valley Region, Southeastern California. Geomorphology, 42, 255-278. https://doi.org/10.1016/S0169-555X(01)00089-7

Pick, M., Picha, J., \& Vyskocil, V. (1973). Theory of the Earth's Gravity Field. Academic Publ. House of the CS Academy of Sciences, Prague 1973.

Prutkina, I., \& Saleh, A. (2009). Gravity and Magnetic Data Inversion for 3D Topography of the Moho Discontinuity in the Northern Red Sea Area, Egypt. Journal of Geodynamics, 47, 237-245. https://doi.org/10.1016/j.jog.2008.12.001

Riad, S. (1977). Shear Zones in North Egypt Interpreted from Gravity Data. Geophysics, 42, 1207-1214. https://doi.org/10.1190/1.1440785

Riad, S., \& El-Etr, H. A. (1985). Bouguer Anomalies and Lithosphere-Crustal Thickness in Uganda. Journal of Geodynamics, 3, 169-186.

https://doi.org/10.1016/0264-3707(85)90027-4

Riad, S., Fouda, A., Refai, E., \& Ghaleb, M. (1983). Preliminary Interpretation of the Re- 
gional Gravity Anomalies of Egypt. In The XVIII General Assembly of the IUGG.

Ribot, M., Klinger, Y., Pons-Branch, E., Lefèvr, M., \& Jónsson, S. (2018). Quantification of Tectonic Uplift along the Dead Sea Fault in Gulf of Aqaba. Geophysical Research Abstracts, 20, EGU2018-12430.

Rybakov, M., Goldshmidt, V., \& Rotstein, Y. (1997). New Regional Gravity and Magnetic Maps of the Levant. Geophysical Research Letters, 24, 33-36.

Saleh, S., Pamukc, O., \& Brimich, L. (2017). The Major Tectonic Boundaries of the Northern Red Sea Rift, Egypt Derived from Geophysical Data Analysis. Contributions to Geophysics and Geodesy, 47, 149-199. https://doi.org/10.1515/congeo-2017-0010

Segev, A., Rybakov, M., Lyakhovsky, V., Hofstetter, A., Tibor, G., Goldshmidt, V., \& Ben Avraham, Z. (2006). The Structure, Isostasy and Gravity Field of the Levant Continental Margin and the Southeast Mediterranean Area. Tectonophysics, 425, 137-157. https://doi.org/10.1016/j.tecto.2006.07.010

Shaked, Y., Marco, S., Lazar, B., Stein, M., Cohen, C., Sass, E., \& Agnon, A. (2002). Late Holocene Shorelines at the Gulf of Aqaba: Migrating Shorelines under Conditions of Tectonic and Sea Level Stability (pp. 1-7). EGU Stephan Mueller Special Publication Series 2 .

Sibson, R. (1983). Fault Zone Models, Heat Flow and the Depth Distribution of Earthquakes in the Continental Crust of the United States. Bulletin of the Seismological Society of America, 72, 151-163.

Spiegal, M. R. (1972). Theory and Problems of Statistics (p. 359). Shaum's Outline Series, New York: McGraw-Hill Book Company.

Steckler, M. S., Berthelot, F., Lyberis, N., \& Le Pichon, X. (1988). Subsidence in the Gulf of Suez: Implications for Rifting and Plate Kinematics. Tectonophysics, 153, 249-270. https://doi.org/10.1016/0040-1951(88)90019-4

Steinitz, G., Bartiv, Y., \& Hunziker, J. (1978). K/Ar Age Determination of Some Miocene-Pliocene Basalts in Israel; Their Significance to the Tectonics of the Rift Valley. Geological Magazine, 115, 329-340. https://doi.org/10.1017/S0016756800037341

Tealeb, A., \& Riad, S. (1986). Regional Gravity Anomalies of Western Saudi Arabia and Their Geological Significance. Egyptian Geophysical Society, 5, 50-78.

Woodside, J. M. (1977). Tectonic Elements and Crust of the Eastern Mediterranean Sea. Marine Geophysical Research, 3, 317-354. https://doi.org/10.1007/BF00285658 